\title{
Chromium (VI) tolerance and bioaccumulation by Candida tropicalis isolated from textile wastewater
}

\author{
Sidra llyas ${ }^{1}$, Dilara A. Bukhari ${ }^{2}$ and Abdul Rehman ${ }^{1 *}$
}

\begin{abstract}
In the present study a yeast strain isolated from industrial wastewater, identified as Candida tropicalis, showed chromium $(\mathrm{Cr})$ tolerance level up to $5 \mathrm{mM}$. Yeast grown in minimal salt medium containing $\mathrm{Cr}(\mathrm{VI})$ ions for $48 \mathrm{~h}$ and crude enzyme extracts were tested for chromate reductase activity. Optimum temperature and pH of chromate reductase were $30^{\circ} \mathrm{C}$ and $\mathrm{pH}$ of 7 . The enzyme activity was greatly enhanced in the presence of divalent metal cations. Total protein profile revealed some protein bands were present in hexavalent chromium [Cr (VI)] treated samples but were absent in non-treated samples, especially low molecular-weight protein bands in the mass range of $<25 \mathrm{kDa}$ with greater intensity in $\mathrm{Cr}(\mathrm{VI})$ treated samples. Yeast cells were able to uptake $\mathrm{Cr}(\mathrm{VI})$ between 21 and $80 \mathrm{mg} \mathrm{g}^{-1}$ within 2-12-d of time, indicating yeast strain promising potential for $\mathrm{Cr}(\mathrm{VI})$ removal from the wastewater. The present study results suggest that $C$. tropicalis is a suitable candidate for bioremediating chromium ions from the contaminated-environment.
\end{abstract}

Keywords: Candida tropicalis, Cr (VI) resistance, Chromate reductase, Bioremediation

\section{Introduction}

One of the most abundant elements on earth is chromium $(\mathrm{Cr})$ existing in various oxidation states ranging from 0 to $+6[1]$. $\mathrm{Cr}$ is used in leather tanning, textile dyeing, chrome electroplating and finishing, metal processing industries, wood treatment, mining equipment, corrosion inhibition in power plants, manufacturing of refractory materials, and pigments. This extensive anthropogenic use has increased its concentration in environment higher than the recommended into the environment $[2,3]$. The United State Environmental Protection Agency has declared it as a priority pollutant [4]. $\mathrm{Cr}$ poses several health threats to humans and has been reported to link to mutagenicity, genotoxicity, carcinogenicity, and allergenicity [5-7]. Generally, industrial effluents contain multiple metals including chromium and chromium salts which have adverse effects on the microbial biota [8].

Chromium exists in several forms but trivalent $\mathrm{Cr}$ (III) and hexavalent $\mathrm{Cr}$ (VI) are the most stable forms [9]. Cr (VI) compounds are 100 times more toxic than $\mathrm{Cr}$ (III) due to having higher solubility, greater permeability through biological membrane systems and their successive interaction with intracellular macromolecules including nucleic acids and proteins $[10,11]$. On the other hand, Cr (III) which is an essential trace element plays a significant role in glucose and fat metabolism by helping the smooth insulin functioning [12] in almost all types of living organisms. Cr (VI) inside the cells is partially reduced to highly unstable $\mathrm{Cr}$ (IV) and $\mathrm{Cr}(\mathrm{V})$ radicals that

\footnotetext{
* Correspondence: rehman.mmg@pu.edu.pk

'Department of Microbiology and Molecular Genetics, University of the

Punjab, Lahore 54590, Pakistan

Full list of author information is available at the end of the article
}

(c) The Author(s). 2020 Open Access This article is licensed under a Creative Commons Attribution 4.0 International License, which permits use, sharing, adaptation, distribution and reproduction in any medium or format, as long as you give appropriate credit to the original author(s) and the source, provide a link to the Creative Commons licence, and indicate if changes were made. The images or other third party material in this article are included in the article's Creative Commons licence, unless indicated otherwise in a credit line to the material. If material is not included in the article's Creative Commons licence and your intended use is not permitted by statutory regulation or exceeds the permitted use, you will need to obtain permission directly from the copyright holder. To view a copy of this licence, visit http://creativecommons.org/licenses/by/4.0/. 
cause oxidative burden through the generation of reactive oxygen species, eventually leading to carcinogenicity $[13,14]$.

Textile industrial effluents usually contain a mixture of various toxic heavy metals such as chromium, cadmium, lead, arsenic and other chemicals like ammonia, salts etc. This industrial wastewater poses serious threat to the aquatic biota and environment. To decontaminate such wastewater generally two treatment strategies are being used; one is through chemicals and other is through living organisms. The chemical treatment is expensive and a source of addition of more chemicals into the environment while biological treatment is cost effective, benign and more reliable [15].

The microbial potential to resist and reduce Cr (VI) into $\mathrm{Cr}$ (III) is regarded as an important phenomenon $[14,15]$ to prevent chromium pollution. The ability of yeast biomass to uptake a variety of heavy metal ions in a wide range of external conditions has been reported by many workers [15-17]. When Cr (VI) enters into the cell via nonspecific sulfate transporters [18] through facilitated diffusion, a gradient by metabolically active cells is established between two sides of the cell membrane. This gradient helps in the enzymatic reduction of $\mathrm{Cr}$ (VI) to $\mathrm{Cr}$ (III) via flavoenzymes and non-enzymatic via ascorbate, reduced glutathione, and nicotinamide adenine dinucleotide phosphate [19]. The response of yeast cells to metal involves several cellular processes like redox reactions $[17,20]$, binding by cytosolic molecules, interactions with cellular organelles [21], and generation of protein-DNA and Cr-DNA adducts, DNA-DNA cross links, and DNA strand breaks [22, 23]. The induction of stress proteins, metal precipitation, metal chelation, Cr-entrapment into membranous organelles, and active efflux has been found in other living organisms in lieu of oxidative stress generated by $\mathrm{Cr}$ [14] that such processes are speculated to occur in yeast cells [24]. However, the exact mechanism of yeast cells-Cr interaction is not yet clear.

Therefore, in the present study a yeast strain isolated from industrial wastewater was evaluated for its tolerance against $\mathrm{Cr}(\mathrm{VI})$. Chromate reductase involved in $\mathrm{Cr}$ (VI) reduction in yeast cells was assayed and the potential of yeast for bioremediation of chromium was also studied. Proteins extracted from yeast strain were further explored through one dimensional gel electrophoresis.

\section{Materials and methods}

\section{Yeast strain and culturing conditions}

Yeast strain, Candida tropicalis [25], isolated from textile industrial wastewater from Sheikupura, Pakistan
(Fig. S1), was cultured on yeast-peptone-dextrose (YPD) agar plates consisted of; [glucose $\left(20 \mathrm{~g} \mathrm{~L}^{-1}\right)$, peptone $(20$ $\left.\mathrm{g} \mathrm{L}^{-1}\right)$, yeast extract $\left(10 \mathrm{~g} \mathrm{~L}^{-1}\right)$, and agar $\left.\left(20 \mathrm{~g} \mathrm{~L}^{-1}\right)\right]$. The medium $\mathrm{pH}$ was maintained at 7 . For each experiment yeast strain was grown anaerobically in minimal salt medium (MSM) containing: [glucose $\left(10 \mathrm{~g} \mathrm{~L}^{-1}\right)$, $\left(\mathrm{NH}_{4}\right)_{2} \mathrm{SO}_{4}\left(1 \mathrm{~g} \mathrm{~L}^{-1}\right), \quad 0.15 \mathrm{~g} \mathrm{~L}^{-1} \quad \mathrm{KH}_{2} \mathrm{PO}_{4}\left(0.15 \mathrm{~g} \mathrm{~L}^{-1}\right)$, $\mathrm{K}_{2} \mathrm{HPO}_{4}, \mathrm{MgSO}_{4} \cdot 7 \mathrm{H}_{2} \mathrm{O}\left(0.1 \mathrm{~g} \mathrm{~L}^{-1}\right), \mathrm{FeSO}_{4}\left(0.026 \mathrm{~g} \mathrm{~L}^{-1}\right)$, and $\left.\mathrm{CaCl}_{2}\left(0.086 \mathrm{~g} \mathrm{~L}^{-1}\right)(\mathrm{pH}=7.0-7.2)\right]$ and was incubated for $24 \mathrm{~h}$ at $30^{\circ} \mathrm{C}$. The $\mathrm{Cr}(\mathrm{VI})$ was introduced into the yeast culture for $48 \mathrm{~h}$ at a concentration of $100 \mathrm{mg}$ $\mathrm{L}^{-1}$.

\section{Effect of $\mathrm{Cr}(\mathrm{VI})$ exposure}

The minimum inhibitory concentration was measured by culturing yeast cells in YPD agar plates containing different concentrations of $\mathrm{K}_{2} \mathrm{CrO}_{7}$ [26]. The yeast cells were successively changed from a given concentration to the next concentration and maximum resistance was determined until the yeast cells were unable to grow as colonies on agar plates containing chromium. The solicitous observations were made regarding any color change in yeast colonies in response to $\mathrm{Cr}$-exposure.

\section{Extraction of protein}

For intracellular chromate reductase activity, yeast cells were obtained by centrifugation at $1500 \mathrm{~g}$ for $10 \mathrm{~min}$, pellet was washed two times with sodium phosphate buffer ( $50 \mathrm{mM}, \mathrm{pH} 7.0)$ and was lysed by sonication for $15 \mathrm{~s}$ with an interval of $60 \mathrm{~s}$ (five times) at $4{ }^{\circ} \mathrm{C}$. The yeast cells free extract obtained by centrifugation was used as a crude enzyme for relative chromate reductase activity. Bradford [27] assay was employed to measure protein concentration with the standard bovine serum albumin used.

\section{Enzyme assay}

Chromate reductase activity was measured through an enzyme assay consisting of crude enzyme, $20 \mu \mathrm{M} \mathrm{Cr}$ $(\mathrm{VI})$, and $0.1 \mathrm{mM} \mathrm{NADH}$ in $50 \mathrm{mM}$ potassium phosphate buffer ( $\mathrm{pH}$ 6.0). The initiation of reaction was done by adding NADH as an electron donor and the reaction assay was incubated for $30 \mathrm{~min}$ at $30^{\circ} \mathrm{C}$ [28] and relative activity (\%) of crude chromate reductase was determined by any comparable change in absorbance with reference to control. An assay mixture having no enzyme or NADH was treated as control. The enzyme concentration required to reduce one $\mu$ mole of $\mathrm{Cr}(\mathrm{VI})$ per min $\mathrm{mL}^{-1}$ at $30^{\circ} \mathrm{C}$ is equal to one-unit enzyme activity under prescribed assay conditions. 


\section{$\mathrm{Cr}(\mathrm{VI})$ reduction}

Diphenylcarbazide method [29] was used to measure the amount of $\mathrm{Cr}$ (VI) in the culture filtrate to further determine the $\mathrm{Cr}$ (IV) reduction potential of yeast strain at a given time. For this, the reaction mixture was kept for $10 \mathrm{~min}$ at room temperature to form a pink-violet colored complex and finally optical density was measured by a spectrophotometer at 540 nm.

\section{Enzyme characteristics}

Chromate reductase activity was determined by incubating the reaction mixture at $30,40,50,70$, and $90^{\circ} \mathrm{C}$ through the standard enzyme assay procedure. Likewise, $\mathrm{pH}$ profiling of chromate reductase was performed at $\mathrm{pH}$ range of 5-9 and the reaction assays were kept at $30{ }^{\circ} \mathrm{C}$ for $30 \mathrm{~min}$. For this, three buffer systems: sodium acetate buffer (pH 5.0-6.0), sodium phosphate buffer, ( $\mathrm{pH} 7.0-8.0)$, and Tris- $\mathrm{HCl}$ buffer ( $\mathrm{pH} 9.0$ ) were used. The assay containing no enzyme was treated as control and was used to determine any optical density change in enzyme assays containing enzyme. For the metal ion effect on enzyme activity, various chloride salts $\left(\mathrm{CaCl}_{2}, \mathrm{MgCl}_{2}\right.$, $\mathrm{HgCl}_{2}, \mathrm{CoCl}_{2}$, and $\mathrm{NaCl}$ ) were used to determine their effects on chromate reductase activity. The reaction assay containing no metal ion was treated as control.

\section{One dimensional gel electrophoresis}

For total cell proteins, one dimensional gel electrophoresis was performed on $12 \%$ polyacrylamide gels. Then, $10 \mathrm{vol} \%$ chilled trichloroacetic acid was used to precipitate protein samples $\left(20 \mu \mathrm{g} \mu \mathrm{L}^{-1}\right)$ and then centrifuged at $11,000 \mathrm{~g}$ at $4{ }^{\circ} \mathrm{C}$ for $15 \mathrm{~min}$. Finally the gel was run at a constant voltage $(120 \mathrm{~V})$ to electrophorese the protein samples according to Laemmli [30].

\section{$\mathrm{Cr}$ (IV) biosorption by yeast strain}

Yeast cells were cultured in MSM medium containing $\mathrm{Cr}$ (VI) under optimum conditions. Then $5 \mathrm{~mL}$ sample from each flask were taken out after a regular interval of time $2,4,6,8,10$, and $12 \mathrm{~d}$ under sterilized conditions. The pellets obtained by centrifugation at $4000 \mathrm{~g}$ for $10 \mathrm{~min}$ were weighted and washed three times with distilled water. Then pellets were divided into almost two equal portions: the first portion was again washed with $0.1 \mathrm{M}$ EDTA three times for $10 \mathrm{~min}$ and metal associated with the yeast cell surface was removed as a soluble fraction. The second portion, treated with $0.2 \mathrm{~N}^{-} \mathrm{HNO}_{3}$ (1:1) for acid digestion, was placed on a hot plate for 30 min. The Atomic Absorption Spectrophotometer was employed to estimate the amount of chromium present in the medium or removed by yeast strain through the air-acetylene burner at $359.3 \mathrm{~nm}[15,31$, 32].

\section{Statistical analysis}

The observations were made and each experiment was run in triplicate. Usually, three separate flasks were maintained for each treatment. Every time three readings were taken from each sample, their mean, and standard error of the mean were calculated. Student's $t$-test was used for significance testing between the samples.

\section{Results and discussion}

\section{$\mathrm{Cr}(\mathrm{VI})$ resistant yeast}

In this study, Cr (VI) was tested for tolerance separately by 11 yeast isolates. C. tropicalis [25] exhibiting the highest ability to tolerate chromium effectively up to 5 $\mathrm{mM}$ was selected for further study. The most favorable temperature and $\mathrm{pH}$ required for yeast growth was found to be $30^{\circ} \mathrm{C}$ and 7.0. The growth (no. of cells) was also decreased under $\mathrm{Cr}(\mathrm{VI})$ stress as compared to the control (Fig. 1).

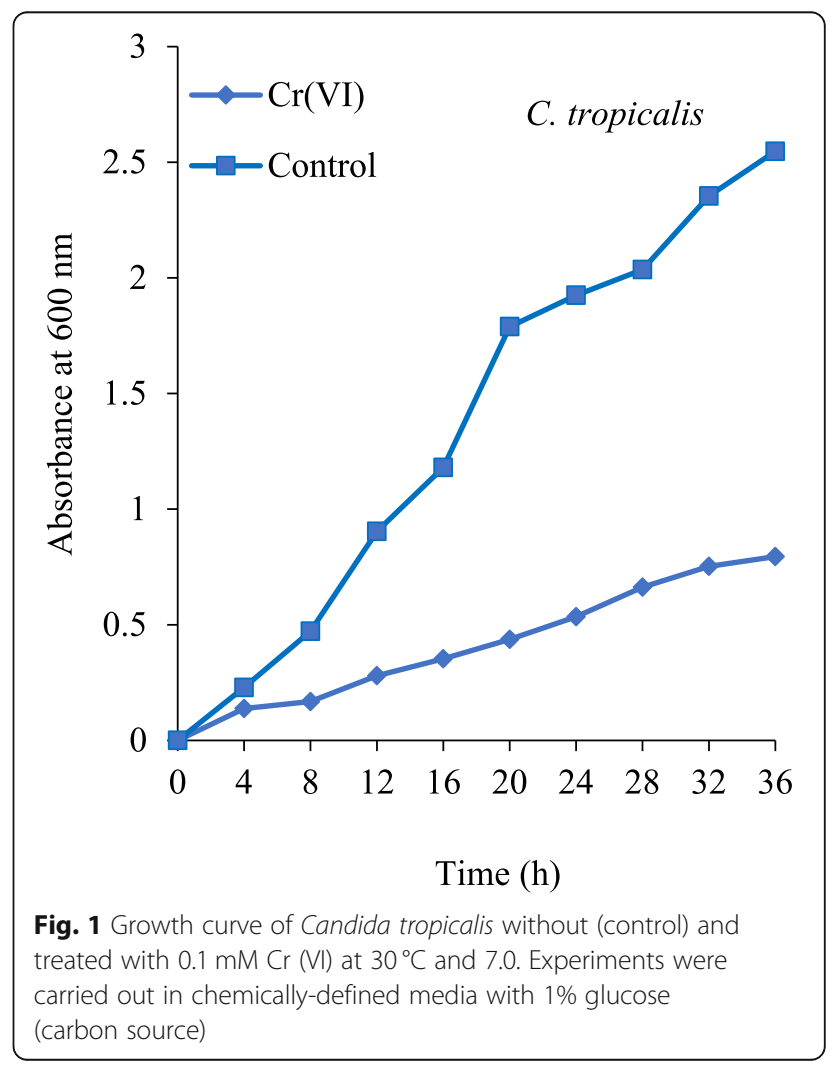


The color of yeast isolate was affected and transformed to green in comparison with the control (Fig. $\mathrm{S} 2$ ), which was due to enzymatic reduction of $\mathrm{Cr}$ (VI) into $\mathrm{Cr}$ (III). The color change of yeast cells clearly indicates the synthesis of specific enzymes which convert $\mathrm{Cr}$ (VI) to $\mathrm{Cr}$ (III). Yeast biomass content was decreased in the presence of $\mathrm{Cr}(\mathrm{VI})$ as compared to the control (Table S1).

An increase in chromate reductase activity was determined in Streptomyces sp. M3 cells when exposed to $\mathrm{Cr}$ (VI) as reported by Das and Chandra [33]. Many researchers have reported enzymatic role in $\mathrm{Cr}$ (VI) reduction obtained from the yeast cells $[25,34$, 35]. Similarly, chromate reductase role in Cr (VI) reduction by many bacterial genera Escherichia, Pseudomonas, Bacillus, and Arthrobacter has also been reported [36, 37]. Similar phenomenon was reported in Candida utilis [20], Candida maltose [38], and fungi, Hypocrea tawa [39], and Aspergillus sp. [40].

Present study has investigated a few aspects of $\mathrm{Cr}$ interaction with yeast cells including resistance, uptake and reduction of $\mathrm{Cr}$ (VI) into $\mathrm{Cr}$ (III). This metalmicrobe interaction is a very intricate process. When metal ions interact with cells then various mechanisms are activated at cellular, genomic, and proteomic level to combat this stress. The studies at molecular and proteomic level can help to understand such delicately regulated mechanisms.

\section{Chromate reductase characteristics}

The crude chromate reductase obtained from C. tropicalis was tested and induced by 4 -fold under $20 \mu \mathrm{M}$ $\mathrm{Cr}$ (VI) stress (Fig. 2). The maximum enzyme activity was determined at $30{ }^{\circ} \mathrm{C}$ and gradually decreased as the temperature increased (Fig. 3a). Similarly, pH experiments confirmed that chromate reductase activity was optimum at $\mathrm{pH} 7$ as compared to the other $\mathrm{pH}$ (Fig. 3b). Our results are in good agreement with the findings of Martorell et al. [41]. A continuous decline was observed with an increase in temperature. Enzyme activity was lost to $21 \%$ by decreasing $\mathrm{pH}$ to 6 and $15 \%$ when increasing $\mathrm{pH}$ to 9 . At $\mathrm{pH}$ value above or below the optimum, a marked decrease in chromate reductase activity was determined. Among bacterial chromate reductases, the optimal temperature varies in the range of $30-50{ }^{\circ} \mathrm{C}[25,42,43]$. Elahi and Rehman [44] reported that optimum chromate reductase activity was achieved at $\mathrm{pH} 6\left(50^{\circ} \mathrm{C}\right)$ in Trichosporon asahii while Rhodotorula mucilaginosa showed maximum activity at $\mathrm{pH} 7\left(30^{\circ} \mathrm{C}\right)$.

The enzyme activity was also sensitive to the tested metal ions, relative activity was increased in the presence of $\mathrm{Mg}^{2+}(98 \%)$ and $\mathrm{Na}^{+}(75 \%)$ while inhibited to

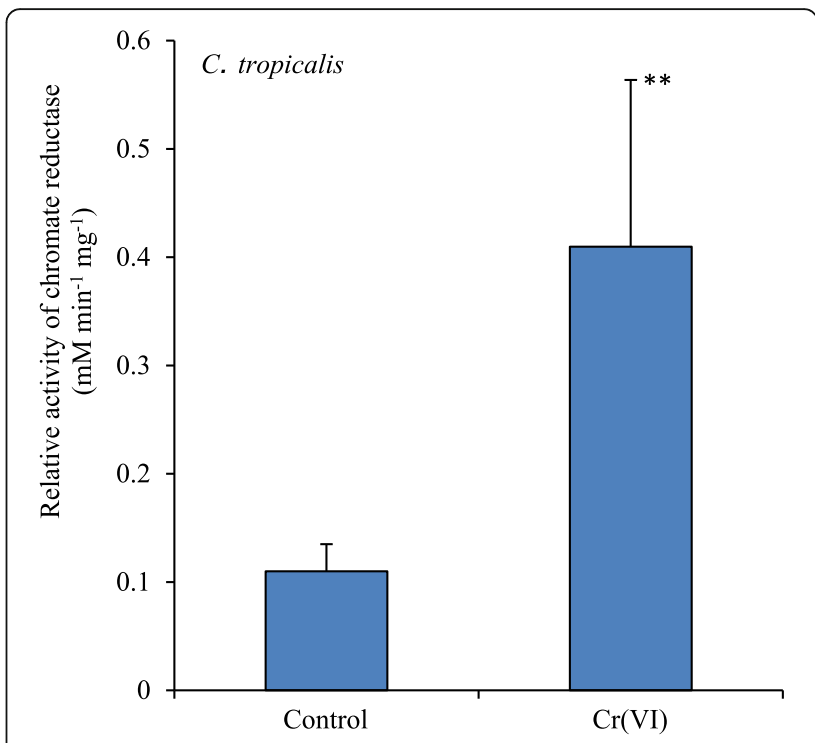

Fig. 2 Relative activity of chromate reductase isolated from $C$. tropicalis. Values were expressed as mean of \pm SD where ${ }^{*} p=0.05$ and ${ }^{* *} p=0.1$ and the experiments were performed in triplicate

$81 \%$ by $\mathrm{Hg}^{2+}$ due to $\mathrm{Hg}^{2+}$ blocking active site of the enzyme (Fig. 3c). Microbial chromate reductase activity could potentially be decreased in the presence of heavy metal ions. In the current study, enzyme activity was highest in the presence of $\mathrm{Mg}^{2+}$ and other divalent metal ions also showed positive effect on chromate reductase activity indicating that the enzyme is not absolutely specific to a single metal. These results also agree with previous reports [25, 43, 45]. Elahi and Rehman [44] reported that activity of chromate reductase from both T. asahii and $R$. mucilaginosa was increased in the presence of $\mathrm{Na}, \mathrm{Ca}, \mathrm{Mg}$, and Co but significantly decreased in the presence of $\mathrm{Hg}$ cations.

\section{Total protein profile}

Total protein profile of $\mathrm{Cr}$-treated and untreated yeast cultures was obtained by one dimension gel electrophoresis. The low molecular-weight protein bands were found in $\mathrm{Cr}$ (VI) treated samples (Fig. 4) and it is possible that these low molecular-weight bands play key role in the protection and survival of microorganisms including yeasts against metal generated oxidative stress. The presence of lower molecular-weight proteins in the mass range of $<25$ $\mathrm{kDa}$ with increased intensity in metal-treated samples indicates their involvement in metal sequestration which eventually leads to metal detoxification. Elahi and Rehman [44] reported that various proteins were overexpressed in T. asahii and $R$. 

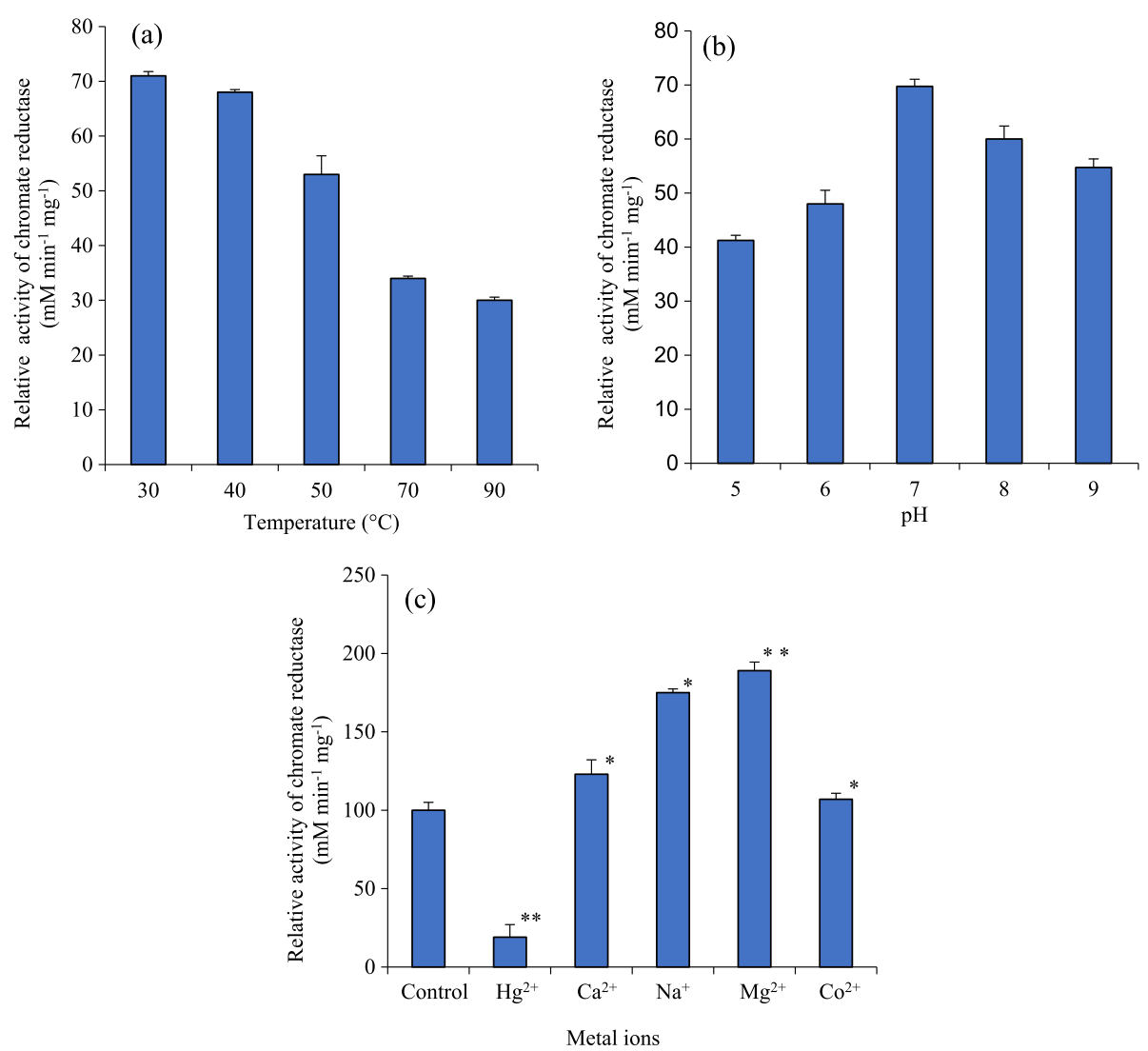

Fig. 3 a Effect of temperature on chromate reductase activity in C. tropicalis. b Effect of pH (5-9) on chromate reductase activity in C. tropicalis. c Metal ions effect on chromate reductase activity pattern of $C$. tropicalis. Concentration of $0.1 \mathrm{mM}$ of each metal ion was used. Values were expressed as mean \pm SD where ${ }^{*} p=0.05$ and ${ }^{* *} p=0.1$ and all experiments were performed in triplicate

mucilaginosa under Cr (VI) stress indicating their possible role in cells protection against metal ions generated oxidative stress. Khan et al. [17] reported that besides cellular redox homeostasis, proteins involved in protein folding, cysteine biosynthesis, and cytoplasmic detoxification response elements were also upregulated in C. tropicalis 3Aer under cadmium stress.

\section{$\mathrm{Cr}$ (VI) biosorption}

The chromium in the medium processed by C. tropicalis was measured using atomic absorption spectroscopy. The highest uptake potential was 15, 21, 28, 35, 45 and $57 \mathrm{mg} \mathrm{g}^{-1}$ (Fig. 5a) and the cells adsorbed 6, 9, 13, 16, 20, and $23 \mathrm{mg} \mathrm{g}^{-1}$ after $2,4,6,8,10$, and $12 \mathrm{~d}$ of incubation, respectively (Fig. 5a). In the present study, C. tropicalis efficiently removed $80 \%$ chromium from the medium within $12 \mathrm{~d}$ of incubation (Fig. 5b). The highest biosorption ability shown by a macro fungus, Amanita rubescens, was $27.3 \mathrm{mg}$

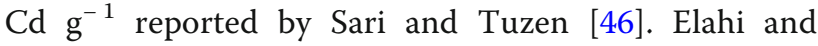
Rehman [44] reported that $R$. mucilaginosa and $T$. asahii were able to accumulate $43-97 \%$ and $35-88 \%$ $\mathrm{Cr}$ (VI) from the medium, respectively.

Yeast cells have the ability to survive in heavy metal ions stress assuring their metabolic activities [47]. The yeast cells can uptake higher concentrations of heavy metals by utilizing the uptake process rather than using biosorption. The highest chromium adsorption by $C$. tropicalis cells reveals more mealbinding sites are present on the cell walls which reflect their ability to uptake metal ions from the medium and eventually remove $\mathrm{Cr}$ (VI) from the wastewater. Rhodotorula sp. Y11 was able to uptake $19.4 \mathrm{mg} \mathrm{Cd} \mathrm{g}^{-1}$ from the medium as reported by $\mathrm{Li}$ and Yuan [48]. Mainly two processes i.e. biosorption (adsorption; ATP independent) and uptake (accumulation, ATP dependent) are involved to detoxify wastewater containing multiple metal ions. Both biosorption and uptake can be influenced in the presence of other metal ions. The use of microbes as compared to the chemical methods is less-expensive, environment-friendly, and can efficiently be used to remove dissolved toxic metal ions from the wastewater even at relatively high metal concentration. This 


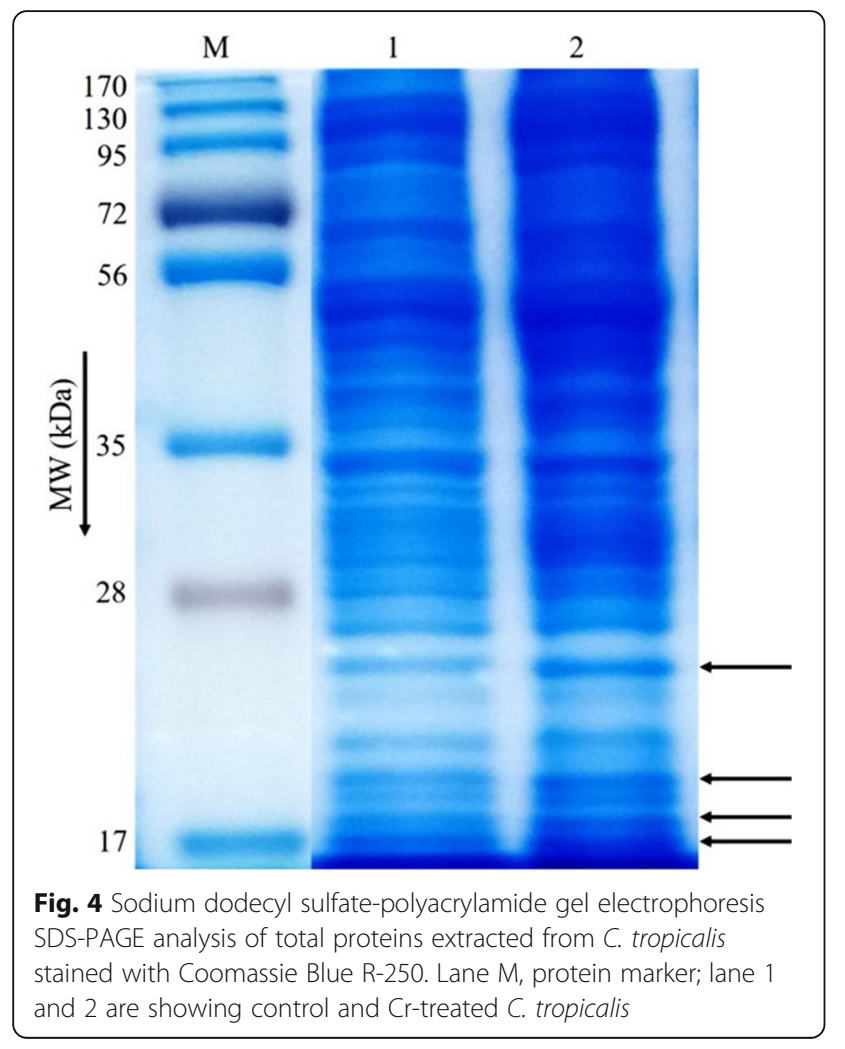

microbially purified wastewater can at least be used for crops irrigation. In this study, C. tropicalis could efficiently remove chromium up to $80 \%$ within $12 \mathrm{~d}$ of incubation.

\section{Conclusions}

In the present study, C. tropicalis showed significant resistance against $\mathrm{Cr}$ (VI) and growth was slowed in Cr-treated cultures as compared to the control. The crude enzyme exhibited maximum activity at $30^{\circ} \mathrm{C}$ (pH 7). The enzyme activity was not affected greatly in the presence of divalent metal ions. The gel electrophoresis revealed several low-molecular weight protein bands with greater intensity in Cr-treated samples as compared to the non-treated samples that may correspond to protein marker. Yeast cells were capable of uptaking noxious and soluble $\mathrm{Cr}$ (VI) and reduced it into less harmful and insoluble $\mathrm{Cr}$ (III) by chromate reductase. Hence, C. tropicalis can be used as biosorbent for $\mathrm{Cr}$ (VI) detoxification from the wastewater laden with toxic chromium ions. Further research work is needed to explore its molecular biology so that it can become an attractive environmental tool for green chemistry.
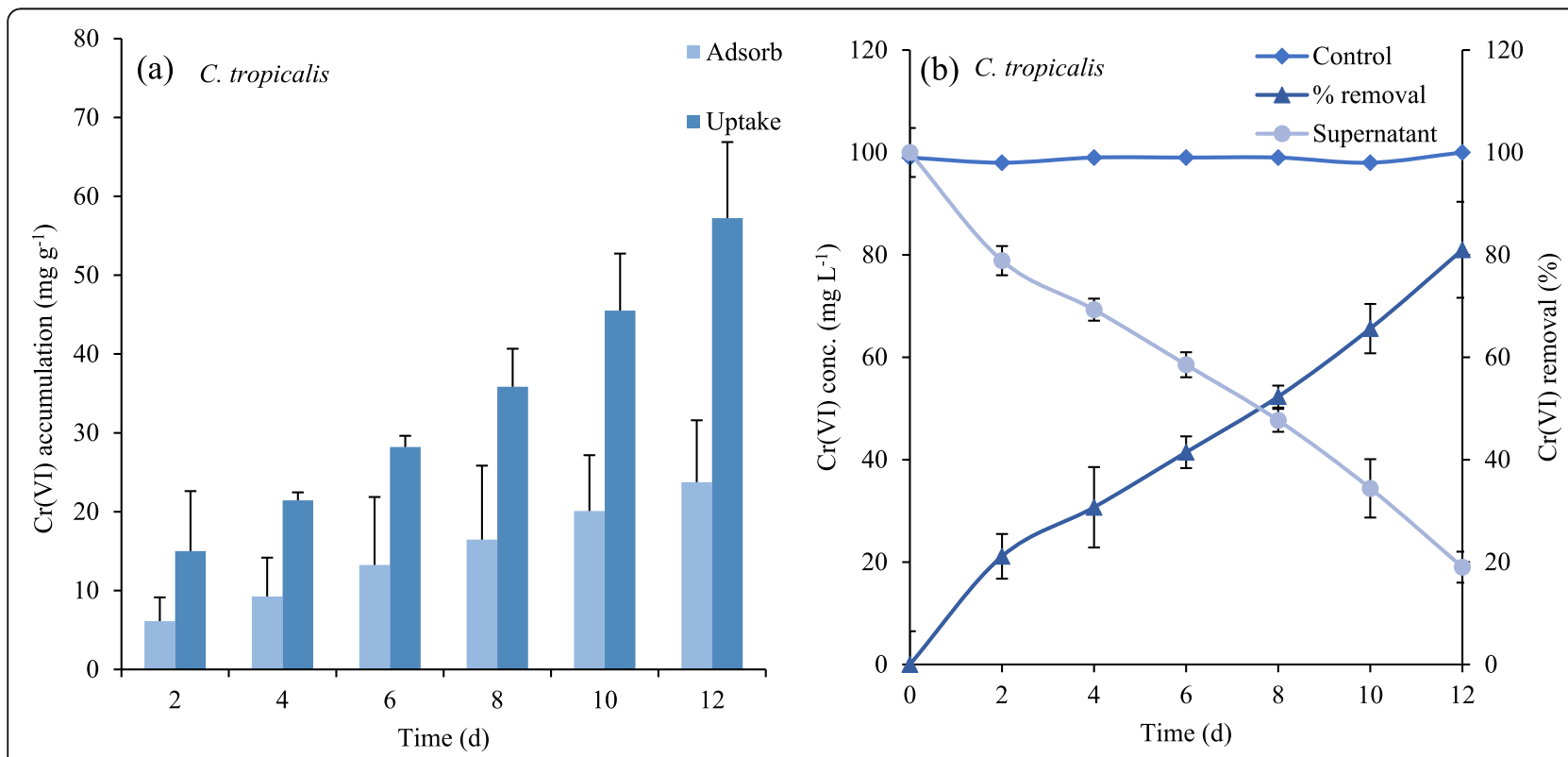

Fig. 5 a Uptake and adsorption of chromium metals ions from culture media by C. tropicalis. b Supernatants were taken out at regular intervals of $2,4,6,8,10$ and $12 \mathrm{~d}$ of incubation (controls contained heavy metal ions but did not contain yeast cells) and percentage removal was calculated at each time-point 


\section{Supplementary Information}

The online version contains supplementary material available at https://doi. org/10.1186/s42834-020-00069-1.

Additional file 1: Table S1. Gram fresh weight (biomass) of Candida tropicalis grown in MSM supplemented with and without chromium. Three biological replicates were used and an equal gram weight was taken for protein extraction. Fig. $\mathbf{S 1}$ Geographical map of district Sheikhupura, Pakistan, from where wastewater samples were collected. Fig. $\mathbf{S 2}$ Hexavalent chromium reduction by C. tropicalis cells augmented with chromium after $24 \mathrm{~h}$ of incubation. Control test tube (yellow in color) only contains chromium while C. tropicalis (green in color) indicates the ability of yeast strain to reduce the hexavalent chromium.

\section{Acknowledgements}

Not applicable.

\section{Authors' contributions}

SI performed experiments and wrote the article. DAB helped in data analysis and in manuscript editing. AR contributed in the design, write up, and final editing of the manuscript. All authors read and approved the manuscript.

\section{Funding}

Not applicable.

\section{Availability of data and materials}

The data used to support the findings of this study are available from the corresponding author upon request.

\section{Competing interests}

The authors have declared that no competing interests exist.

\section{Author details}

'Department of Microbiology and Molecular Genetics, University of the Punjab, Lahore 54590, Pakistan. ${ }^{2}$ Department of Zoology, Government College University Lahore, Lahore 54000, Pakistan.

Received: 1 May 2020 Accepted: 30 October 2020 Published online: 23 November 2020

\section{References}

1. Emsley J. Chromium. Nature's building blocks: an A-Z guide to the elements. 2nd. New York: Oxford University Press. 2001; 495-8.

2. Juvera-Espinosa J, Morales-Barrera L, Cristiani-Urbina E. Isolation and characterization of a yeast strain capable of removing $\mathrm{Cr}(\mathrm{VI})$. Enzyme Microb Tech. 2006:40:114-21.

3. Ibrahim ASS, El-Tayeb MA, Elbadawi YB, Al-Salamah AA, Antranikian G. Hexavalent chromate reduction by alkaliphilic Amphibacillus sp. KSUCr3 is mediated by copper-dependent membrane-associated $\mathrm{Cr}(\mathrm{VI})$ reductase. Extremophiles. 2012;16:659-68.

4. USEPA. Cleaning Up the Nation's Waste Sites: Markets and Technology Trends. Cincinnati: US Environmental Protection Agency; 2004.

5. Dayan AD, Paine AJ. Mechanisms of chromium toxicity, carcinogenicity and allergenicity: review of the literature from 1985 to 2000. Hum Exp Toxicol. 2001;20:439-51. https://journals.sagepub.com/doi/pdf/10.1191/0960327016 82693062

6. Thacker U, Parikh R, Shouche Y, Madamwar D. Reduction of chromate by cell-free extract of Brucella sp. isolated from $\mathrm{Cr}(\mathrm{VI})$ contaminated sites. Bioresour Technol. 2007:98:1541-7.

7. Thompson CM, Fedorov Y, Brown DD, Suh M, Proctor DM, Kuriakose L, et al. Assessment of $\mathrm{Cr}(\mathrm{VI})$-induced cytotoxicity and genotoxicity using high content analysis. PloS One 2012;7:e42720.

8. Stasinakis AS, Thomaidis NS, Mamais D, Papanikolaou EC, Tsakon A, Lekkas TD. Effects of chromium (VI) addition on the activated sludge process. Water Res. 2003;37:2140-8.

9. Bai ZH, Harvey LM, McNeil B. Oxidative stress in submerged cultures of fungi. Crit Rev Biotechnol. 2003;23:267-302.

10. Anderson RA. Chromium as an essential nutrient for humans. Regul Toxicol Pharm. 1997;26:S35-41.
11. Kotas J, Stasicka Z. Chromium occurrence in the environment and methods of its speciation. Environ Pollut. 2000;107:263-83.

12. Anderson RA, Polansky MM, Bryden NA. Stability and absorption of chromium and absorption of chromium histidinate complexes by humans. Biol Trace Elem Res. 2004;101:211-8.

13. Ackerley DF, Barak Y, Lynch SV, Curtin J, Matin A. Effect of chromate stress on Escherichia coli K-12. J Bacteriol. 2006;188:3371-81.

14. Cervantes C, Campos-Garcia J, Devars S, Gutierrez-Corona F, Loza-Tavera H, Torres-Guzman JC, et al. Interactions of chromium with microorganisms and plants. FEMS Microbiol Rev. 2001;25:335-47.

15. Elahi A, Rehman A. Multiple metal resistance and $\mathrm{Cr}^{6+}$ reduction by bacterium, Staphylococcus sciuri A-HS1, isolated from untreated tannery effluent. J King Saud Univ Sci. 2019;31:1005-13.

16. Villegas LB, Amoroso MJ, De Figueroa LIC. Copper tolerant yeasts isolated from polluted area of Argentina. J Basic Microb. 2005:45:381-91.

17. Khan Z, Rehman A, Nisar MA, Zafar S, Hussain SZ, Zerr I, et al. Molecular basis of $\mathrm{Cd}^{+2}$ stress response in Candida tropicalis. Appl Microbiol Biot. 2017; 101:7715-28.

18. Wiegand $\mathrm{HJ}$, Ottenwalder $\mathrm{H}$, Bolt HM. Fast uptake kinetics invitro of $51 \mathrm{Cr}(\mathrm{VI})$ by red blood cells of man and rat. Arch Toxicol. 1985;57:31-4.

19. Pesti M, Gazdag Z, Belagyi J. In vivo interaction of trivalent chromium with yeast plasma membrane, as revealed by EPR spectroscopy. FEMS Microbiol Lett. 2000;182:375-80.

20. Muter O, Patmalnieks A, Rapoport A. Interrelations of the yeast Candida utilis and $\mathrm{Cr}(\mathrm{VI})$ : metal reduction and its distribution in the cell and medium. Process Biochem. 2001;36:963-70.

21. Batic M, Raspor P. Uptake and bioaccumulation of $\mathrm{Cr}$ (III) in yeast Saccharomyces cerevisiae. Food Technol Biotech. 1998;36:291-7.

22. Cheng L, Liu SJ, Dixon K. Analysis of repair and mutagenesis of chromiuminduced DNA damage in yeast, mammalian cells, and transgenic mice. Environ Health Persp. 1998;106:1027-32.

23. Zahoor $\mathrm{A}$, Rehman $\mathrm{A}$. Isolation of $\mathrm{Cr}(\mathrm{VI})$ reducing bacteria from industrial effluents and their potential use in bioremediation of chromium containing wastewater. J Environ Sci-China. 2009:21:814-20.

24. Raspor P, Batič M, Jamnik P, Dj. Josić, Milačič R, Paš M, et al. The influence of chromium compounds on yeast physiology: a review. Acta Microbiol Imm H. 2000;47:143-73.

25. Ilyas S, Rehman A. Oxidative stress, glutathione level and antioxidant response to heavy metals in multi-resistant pathogen, Candida tropicalis. Environ Monit Assess. 2015:187:4115.

26. Ilyas S, Rehman A, Varela AC, Sheehan D. Redox proteomics changes in the fungal pathogen Trichosporon asahii on arsenic exposure: identification of protein responses to metal-induced oxidative stress in an environmentallysampled isolate. PloS One 2014;9:e102340.

27. Bradford MM. A rapid and sensitive method for the quantitation of microgram quantities of protein utilizing the principle of protein-dye binding. Anal Biochem. 1976:72:248-54.

28. Sarangi A, Krishnan C. Comparison of in vitro $\mathrm{Cr}(\mathrm{VI})$ reduction by CFEs of chromate resistant bacteria isolated from chromate contaminated soil. Bioresour Technol. 2008;99:4130-7.

29. APHA. Standard methods for the examination of water and wastewater. 19th ed. Washington, DC: American Public Health Association; 1995.

30. Laemmli UK. Cleavage of structural proteins during assembly of head of bacteriophage T4. Nature. 1970;227:680-5.

31. Li Z, Yuan H, Hu X. Cadmium-resistance in growing Rhodotorula sp. Y11. Bioresour Technol. 2008;99:1339-44

32. Rehman A, Anjum MS. Cadmium uptake by yeast, Candida tropicalis, isolated from industrial effluents and its potential use in wastewater cleanup operations. Water Air Soil Poll. 2010;205:149-59.

33. Das S, Chandra AL. Chromate reduction in Streptomyces. Experientia. 1990; 46:731-3.

34. He MY, Li XY, Guo LA, Miller SJ, Rensing C, Wang GJ. Characterization and genomic analysis of chromate resistant and reducing Bacillus cereus strain SJ1. BMC Microbiol. 2010:10:221.

35. Masood F, Malik A. Hexavalent chromium reduction by Bacillus sp. strain FM1 isolated from heavy-metal contaminated soil. B Environ Contam Tox. 2011;86:114-9.

36. Desai C, Jain K, Madamwar D. Hexavalent chromate reductase activity in cytosolic fractions of Pseudomonas sp. G1DM21 isolated from $\mathrm{Cr}(\mathrm{VI})$ contaminated industrial landfill. Process Biochem. 2008:43:713-21. 
37. Elangovan R, Philip L, Chandraraj K. Hexavalent chromium reduction by free and immobilized cell-free extract of Arthrobacter rhombi-RE. Appl Biochem Biotech. 2010;160:81-97.

38. Ramirez-Ramirez R, Calvo-Mendez C, Avila-Rodriquez M, Lappe P, Ulloa M, Vazquez-Juarez R, et al. Cr (VI) reduction in a chromate-resistant strain of Candida maltosa isolated from the leather industry. Anton Leeuw. 2004;85: 63-8.

39. Morales-Barrera L, Guillen-Jimenez FD, Ortiz-Moreno A, Villegas-Garrido TL, Sandoval-Cabrera A, Hernandez-Rodriguez $\mathrm{CH}$, et al. Isolation, identification and characterization of a Hypocrea tawa strain with high $\mathrm{Cr}(\mathrm{VI})$ reduction potential. Biochem Eng J. 2008;40:284-92.

40. Srivastava S, Thakur IS. Isolation and process parameter optimization of Aspergillus sp. for removal of chromium from tannery effluent. Bioresour Technol. 2006;97:1167-73.

41. Martorell MM, Fernandez PM, Farina JI, Figueroa LIC. Cr (VI) reduction by cell-free extracts of Pichia jadinii and Pichia anomala isolated from textiledye factory effluents. Int Biodeter Biodegr. 2012;71:80-5.

42. Bae WC, Lee HK, Choe YC, Jahng DJ, Lee SH, Kim SJ, et al. Purification and characterization of NADPH-dependent $\mathrm{Cr}(\mathrm{VI})$ reductase from Escherichia coll ATCC 33456. J Microbiol. 2005:43:21-7.

43. Elangovan R, Abhipsa S, Rohit B, Ligy P, Chandraraj K. Reduction of Cr (VI) by a Bacillus sp. Biotechnol Lett. 2006;28:247-52.

44. Elahi A, Rehman A. Oxidative stress, chromium-resistance and uptake by fungi: isolated from industrial wastewater. Braz Arch Biol Techn. 2017;60: e17160394.

45. Camargo FAO, Bento FM, Okeke BC, Frankenberger WT. Hexavalent chromium reduction by an actinomycete, Arthrobacter crystallopoietes ES 32. Biol Trace Elem Res. 2004;97:183-94.

46. Sari A, Tuzen M. Kinetic and equilibrium studies of biosorption of Pb (II) and $\mathrm{Cd}$ (II) from aqueous solution by macrofungus (Amanita rubescens) biomass. J Hazard Mater. 2009;164:1004-11.

47. Malik A. Metal bioremediation through growing cells. Environ Int. 2004;30: 261-78.

48. Li ZJ, Yuan HL. Characterization of cadmium removal by Rhodotorula sp. Y11. Appl Microbiol Biot. 2006;73:458-63.

\section{Publisher's Note}

Springer Nature remains neutral with regard to jurisdictional claims in published maps and institutional affiliations.

Ready to submit your research? Choose BMC and benefit from:

- fast, convenient online submission

- thorough peer review by experienced researchers in your field

- rapid publication on acceptance

- support for research data, including large and complex data types

- gold Open Access which fosters wider collaboration and increased citations

- maximum visibility for your research: over $100 \mathrm{M}$ website views per year

At BMC, research is always in progress.

Learn more biomedcentral.com/submissions 